\title{
Krajobraz po reformie. Zbiorowa reprezentacja praw i interesów zatrudnionych niebędących pracownikami
}

The legal landscape after the reform. Collective representation of non-employees' rights and interests

\author{
dr Piotr Grzebyk
}

Uniwersytet Warszawski, Wydział Prawa i Administracji,

Katedra Prawa Pracy i Polityki Społecznej

p.grzebyk@wpia.uw.edu.pl

\section{dr hab. prof. UW Łukasz Pisarczyk}

Uniwersytet Warszawski, Wydział Prawa i Administracji,

Katedra Prawa Pracy i Polityki Społecznej

1.pisarczyk@wpia.uw.edu.pl

Streszczenie Autorzy koncentrują się na nowelizacji ustawy o związkach zawodowych dokonanej ustawą z 5 lipca 2018 r. o zmianie ustawy o związkach zawodowych oraz niektórych innych ustaw (DzU poz. 1608) i wpływie nowych regulacji na sytuację prawną zatrudnionych niebędących pracownikami w sferze zbiorowego prawa pracy.

Słowa kluczowe: pracownik, osoba wykonująca pracę zarobkową, niestandardowi pracownicy, zakres podmiotowy praw zbiorowych.

Summary The paper focuses on of 5 July 2018 act amending trade unions act of 1991 and other acts and impacts of new regulations on legal position of workers who are not employees in collective labour law field.

Keywords: employee, worker, person conducting a paid work, wage and salaried worker, non-standard workers, ratione personae of collective rights.

JEL: K31

Str. 81-98

\section{Bibliografia}

Baran, K. W. (2018). O zakresie prawa koalicji w związkach zawodowych po nowelizacji prawa związkowego z 5 lipca 2018 r. Praca i Zabezpieczenie Społeczne, (9).

Berg, J. Aleksynski, M. De Stefano, V. Humblet, M. (2018). W: F. Hendrickx, V. De Stefano (red.), Non-standard Employment Around the World: Regulatory Answers to Face Its Chalenges Game Changers in Labour Law. Shaping the F ture of Work. Alphen aan 
den Rijn: Wolters Kluwer.

Blanpain, R. (2013). European Labour Law. Alphen aan den Rijn: Kluwer Law International.

Craven, M. C. R. (2002). The International Covenant on Economic, Social and Cultural Rights. A Perspective on its Development. Oxford: OUP.

Creightont, B. McCrystal, S. (2015-2016). Who is a ,Worker”in International Law. Comp. Lab. L. \& Pol'y J., (37).

Duraj, T. (2018). Prawo koalicji osób zatrudnionych na własny rachunek. W: J. Stelina, J. Szmit (red.), Osoby pozostające w zatrudnieniu pracowniczym w projektach zbiorowego prawa pracy. Zbiorowe prawo zatrudnienia. Warszawa: Wolters Kluwer.

Dzienisiuk, D. (2016). Prawo pracy a prawo ubezpieczeń społecznych. Warszawa.

Florczak, I. (2013). Możliwość objęcia postanowieniami układu zbiorowego osób zatrudnionych na podstawie umów cywilnoprawnych. W: Z. Góral (red.), Układy zbiorowe pracy. W stulecie urodzin Profesora Wactawa Szuberta. Warszawa: Wolters Kluwer.

Florek, L. (1990). Ochrona praw i interesów pracownika. Warszawa.

Florek, L. (2016). Ochrona pracowników jako słabszej strony stosunku pracy. W: M. Boratyńska (red.), Ochrona stabszej strony stosunku prawnego. Księga jubileuszowa ofiarowana Profesorowi Adamowi Zielińskiemu. Warszawa: Wolters Kluwer.

Gersdorf, M. (2013). Prawo zatrudnienia. Warszawa: LexisNexis

Główny Urząd Statystyczny. (2018). Pracujący w gospodarce narodowej w 2017 r. Warszawa: Główny Urząd Statystyczny.

Goździewicz, G. (2010). Układy zbiorowe pracy jako podstawowy instrument działalności związków zawodowych. W: A. WypychŻywicka, M. Tomaszewska, J. Stelina (red.), Zbiorowe prawo pracy w XXI wieku. Gdańsk: Wydawnictwo UG.

Gómez Munoz, J. M. (2017). Re-addressing Self-employment: Spain and the New Entrepreneurship W: E. Ales, O. Deinert, J. Kenner (red.), Core and Contingent Work in the European Union. A Comparative Analysis. Oxford-Portland-Oregon: Hart Publishing.

Góral, Z. (2011). O kodeksowym katalogu zasad indywidualnego prawa pracy. Warszawa: Wolters Kluwer

Gyulavári, T. (2017). Labour Law Reforms in the Eastern European Member States. W: T. Davuslis (red.), Labour Law Reforms in Eastern and Western Europe. Bruksela: Peter Lang.

Hajn, Z. (2002). Ustawowy model organizacji polskiego ruchu związkowego i jego wpływ na zbiorowe stosunki pracy. W: M. Matey-Tyrowicz, L. Nowacki, B. Wagner (red.), Prawo pracy a wyzwania XXI wieku. Księga jubileuszowa Profesora Tadeusza Zielinskiego. Warszawa: Biuro Rzecznika Praw Obywatelskich.

Hajn, Z. (2010). Prawo zrzeszania się w związkach zawodowych - prawo pracowników czy prawo ludzi pracy. W: A. Wypych-Żywicka, M. Tomaszewska, J. Stelina (red.), Zbiorowe prawo pracy w XXI wieku. Gdańsk: Wydawnictwo UG.

Hajn, Z. (2013). Zbiorowe prawo pracy. Zarys systemu. Warszawa.

Heuschmid, J. (2011). Der Arbeitskampf in EU-Recht. W: W. Däubler (red.), Arbeitsrecht. Handbuch für die Rechtspraxis. Baden-Baden: Nomos.

International Labour Office. (2016). Non-standard employment around the world: Understanding challenges, shaping prospects. Genewa: International Labour Office.

IWS. (2015). P. Grzebyk, Analiza orzecznictwa sq̨owego $w$ sprawach o ustalenie istnienia stosunku pracy. Zatrudnienie pracownicze a zatrudnienie cywilnoprawne, https://docplayer.pl/15956945-Analiza-orzecznictwasadowego-wsprawach-o-ustalenie-istnienia-stosunkupracy-zatrudnienie-pracownicze-a-zatrudnieniecywilnoprawne.html

Kocher, E. (2017). W: M. Pechstein, C. Nowak, U. Häde (red.), Frankfurter Kommentar zu EUV, GRC und AEUV. Tybinga: Mohr Siebeck.

Kohte, W. Rosendahl, C. (2013). Standard and non-standard work in Germany. W: J. Buelens, J. Pearson (red.), Standard work: an anachronism? Antwerp-Cambridge: Intersentia.

Kosmol, M. (2018). Unikanie zawierania umów o pracę (na czas nieokreślony) przez stosowanie umów cywilnoprawnych komentarz do reformy prawa pracy w Niemczech. Praca i Zabezpieczenie Spoteczne, (8).

Kulig, K., (2015). Doraźne czynności związkowe. Prawo podmiotowe pracownika czy prawo organizacji związkowej? Praca $i$ Zabezpieczenie Spoleczne, (8).

Lamine, A. Prassl, J. (2018). Collective Autonomy for OnDemand Workers? Normative Arguments, Current Practices and Legal Ways Forward. W: S. Laulom (red.), Collective Bargaining Developments in Times of Crisis. Bulletin of Comparative Labour Relations, (99). Alphen aan den Rijn: Kluwer Law International.

Latos-Miłkowska, M. (2010). Przedstawiciele pracowników wyłaniani w trybie przyjętym u pracodawcy. Praca i Zabezpieczenie Spoleczne, (10).

Musiała, A. (2011). Zatrudnienie niepracownicze. Warszawa: Difin.

Oniszczuk, J. (2014). W: K. W. Baran (red.), System zbiorowego prawa pracy. Tom V. Warszawa: Wolters Kluwer.

Pedersini, R. Coletto, D. (2010). Self-employed workers: industrial relations and working conditions. European Foundation for the Improvement of Living and Working Conditions.

Podgórska-Rakiel, E. (2014). Konieczność nowelizacji prawa polskiego w kwestii wolności związkowych z perspektywy Międzynarodowej Organizacji Pracy. MOPR, (10). 
Raczkowski, M. (2018). Oddziaływanie układu zbiorowego pracy na osoby niebędące pracownikami. Praca $i$ Zabezpieczenie Spoteczne, (2).

Rączka, K. (2010). Szczególna ochrona trwałości stosunku pracy działacza związkowego. W: A. Wypych-Żywicka, M. Tomaszewska, J. Stelina (red.). Zbiorowe prawo pracy wXXI wieku. Gdańsk: Wydawnictwo UG.

Sanetra, W. (1998). Konstytucyjne prawo do rokowań, Praca i Zabezpieczenie Spoleczne, (4).

Sanetra, W. (2010a). Dialog społeczny jako element ustroju społecznego i politycznego w świetle Konstytucji RP. W: A. Wypych-Żywicka, M. Tomaszewska, J. Stelina (red.), Zbiorowe prawo pracy w XXI wieku. Gdańsk: Wydawnictwo UG.

Sanetra, W. (2010b). Prawo pracy po Traktacie z Lizbony. Europejski Przeglad Sadowy, (2).

Servais, J-M. (2017). International Labour Law. Alphen aan den Rijn: Wolters Kluwer.

Seweryński, M. (2006). Problemy legislacyjne zbiorowego prawa pracy. W: M. Matey-Tyrowicz, T. Zieliński (red.), Prawo pracy RP w obliczu przemian. Warszawa: CH Beck.

Seweryński, M. (2013). Uwagi o przyszłości układów zbiorowych pracy. W: Z. Góral (red.), Układy zbiorowe pracy. W stulecie urodzin Profesora Wactawa Szuberta. Warszawa: Wolters Kluwer.

Sobczyk, A. (2010). Przedstawicielstwa pozazwiązkowe w systemie zbiorowej reprezentacji pracowników — stan obecny i kierunki zmian. W: A. Wypych-Żywicka, M. Tomaszewska, J. Stelina (red.), Zbiorowe prawo pracy w XXI wieku. Gdańsk: Wydawnictwo UG.

Sobczyk, A. (2014). Prawo i człowiek pracujący — między ochroną godności a równości. W: M. Skąpski, K. Ślebzak (red.), Aksjologiczne podstawy prawa pracy i ubezpieczeń spolecznych. Poznań.

Stelina, J. (2018). Zbiorowe prawo zatrudnienia — podstawowe założenia teoretyczne. W: J. Stelina, J. Szmit (red.), Osoby pozostajace $w$ zatrudnieniu pracowniczym $w$ projektach zbiorowego prawa pracy. Zbiorowe prawo zatrudnienia. Warszawa: Wolters Kluwer.

Stelina, J. Szmit, J. Zieleniecki, M. (2018). W: J. Stelina, J. Szmit (red.), Osoby pozostające w zatrudnieniu pracowniczym $w$ projektach zbiorowego prawa pracy. Zbiorowe prawo zatrudnienia. Warszawa: Wolters Kluwer.

Supiot, A. (1999). Zatrudnienie pracownicze i zatrudnienie niezależne. W: Referaty na VI Europejski Kongres Prawa Pracy $i$ Zabezpieczenia Spolecznego. Warszawa: Scholar.

Świątkowski A. M. (2015). Prawo do wolności zrzeszania się i uprawnień pokrewnych. Monitor Prawa Pracy, (9).

Świątkowski, A. M. (2016). Związki zawodowe w kościołach i innych związkach wyznaniowych. Państwo i Prawo, (3).

Van Hiel, I. (2013). The Right to Form and Join Trade Unions Protected by Article 11 ECHR. W: F. Dorssemont, K. Lörcher, I. Schömann (red.), The European Convention on Human Rights and the Employment Relation. Oxford-Portland-Oregon: Hart Publishing.

Walczak, K. (2016). Wynagrodzenie minimalne w umowach zlecenia i o świadczenie usług — zagadnienia doktrynalne i praktyczne. Monitor Prawa Pracy, (8 i 9).

Zieliński, T. (1986). Prawo pracy. Zarys systemu. Część I. Ogólna. Warszawa-Kraków.

Zöllner, W. Loritz, K. -G. Hergenröder, C. W. (2015). Arbeitsrecht. München: CH Beck. 